\title{
A new species of Australotaenia (Cestoda: Proteocephalidea) from a snake in Cambodia: host switching or postcyclic parasitism in a distant region?
}

\author{
Alain de Chambrier ${ }^{1}$, Tomáš Scholz ${ }^{2}$ \\ ${ }^{1}$ Department of Invertebrates, Natural History Museum, P.O. Box 6434, CH-1211 Geneva 6, Switzerland; \\ ${ }^{2}$ Institute of Parasitology, Biology Centre of the Academy of Sciences of the Czech Republic, Branišovská 31, 37005 České \\ Budějovice, Czech Republic
}

\begin{abstract}
Australotaenia de Chambrier et de Chambrier, 2010 has been proposed to accommodate two species of proteocephalidean cestodes from hylid frogs (Litoria spp.) in Australia. Recently, apparently congeneric cestode, for which the name A. bunthangi sp. $\mathrm{n}$. is proposed, was found in the homalopsid snake Enhydris enhydris (Schneider) (Serpentes: Homalopsidae) from South-East Asia (Cambodia). This finding indicates a much wider range of definitive hosts of species of this genus, i.e. amphibians and reptiles, which is exceptional among proteocephalideans. Postcyclic parasitism, i.e. predation of the definitive host infected with sexually mature parasites, cannot be excluded but does not seem to be probable. In addition, the occurrence of $A$. bunthangi in the former Indochina extends the range of the geographical distribution of the genus to another zoogeographical region. The new species differs from both species of Australotaenia in the relative size of an apical organ, the diameter of which equals to that of suckers (versus much smaller in the remaining species, in which the width of the apical organ represents less than $2 / 3$ of the diameter of the suckers), much smaller scolex and suckers (width $150 \mu \mathrm{m}$ and diameter of suckers 50-55 $\mu \mathrm{m}$ versus $245-420 \mu \mathrm{m}$ and 100-140 $\mu \mathrm{m}$, respectively), and longer body (224 mm versus 57-121 mm). In addition, A. bunthangi differs from A. hylae (Johnston, 1912) (type-species of the genus) by the number of testes (46-64 versus 74-106 in A. hylae) and by the ovary width/proglottis width ratio (55-65\% versus $68-71 \%$ in A. hylae). Australotaenia bunthangi differs from A. grobeli de Chambrier et de Chambrier, 2010 by relative size of the cirrus-sac (its length represents $18-24 \%$ of the width of the proglottis versus $27-33 \%$ in $A$. grobeli) and by the diameter of the embryophore (25-27 $\mu \mathrm{m}$ versus $18-23 \mu \mathrm{m}$ in $A$. grobeli).
\end{abstract}

Keywords: taxonomy, zoogeography, tapeworms, helminths, Reptilia, South East Asia, Indomalayan Region

Australotaenia de Chambrier et de Chambrier, 2010 has recently been proposed to accommodate two species of proteocephalidean tapeworms (Cestoda) found in amphibians [hylid frogs Litoria aurea (Lesson) and L. moorei (Copland)] in Australia (de Chambrier and de Chambrier 2010), namely A. hylae (Johnston, 1912) and A. grobeli de Chambrier et de Chambrier, 2010. The genus is characterized by several morphological traits unique among proteocephalideans and has been supposed to include exclusively parasites of hylid frogs in Australia (de Chambrier and de Chambrier 2010). Its generic name was thus derived from this assumed endemic distributional area of its species in Australia. Surprisingly, an apparently congeneric tapeworm was found in the intestine of the homalopsid snake, Enhydris enhydris (Schneider), in Cambodia, i.e. from unrelated host in a distant country of another zoogeographical region. Therefore, a new species is described in the present paper and the geographical distribution and host spectrum of species of Australotaenia are discussed.

\section{MATERIALS AND METHODS}

A single tapeworm was found in the small intestine of one of two Enhydris enhydris (Serpentes: Homalopsidae) snakes, purchased in the market in Siem Reap, northwestern Cambodia. Snakes examined were dead, but still fresh and the tapeworm found was alive. It was fixed with hot $4 \%$ neutral formalin and subsequently stored in $75 \%$ ethanol, then stained with Mayer's hydrochloric carmine, dehydrated in an ethanol series, cleared with eugenol (clove oil), and mounted as a permanent preparation in Canada balsam. For histology, pieces of the strobila were embedded in paraffin, transversely sectioned at $12-15 \mu \mathrm{m}$ intervals, stained with Weigert's hematoxylin, and counterstained with $1 \%$ eosin $\mathrm{B}$ acidified with concentrated acetic acid (see de Chambrier 2001, Oros et al. 2010). Eggs were studied and illustrated in distilled water.

All measurements are given in micrometres unless otherwise indicated. Abbreviations used in the description are as follows: $\mathrm{x}=$ mean; $\mathrm{n}=$ number of measurements; $\mathrm{AOD} / \mathrm{DS}=$ diameter of the apical organ/diameter of suckers; $\mathrm{CV}=$ coefficient of variation (mean/standard deviation, expressed in \%). New material studied has been deposited in the helminthological collections

Address for correspondence: A. de Chambrier, Natural History Museum, P.O. Box 6434, CH-1211 Geneva 6, Switzerland. Phone: +41 224 186 319 ; Fax: +41 224186 301; E-mail: alain.dechambrier@ville-ge.ch 
of the Natural History Museum, Geneva, Switzerland (acronym MHNG-PLAT) and the Institute of Parasitology, České Budějovice, Czech Republic (IPCAS).

\section{RESULTS}

\section{Australotaenia bunthangi sp. n.}

Figs. 1-8

Description (based on holotype): Proteocephalidae, Acanthotaeniinae. Total length $224 \mathrm{~mm}$, maximum width 830 , body dorsoventrally flattened, with last proglottides elongate, much longer than wide (ratio $1: 2.85$ ). Strobila acraspedote, anapolytic, composed of more than 300 proglottides in total: 148 immature proglottides, $31 \mathrm{ma}-$ ture proglottides, 51 pregravid proglottides and 74 gravid proglottides (last proglottides cut off for DNA analyses). Immature and mature proglottides wider than long to longer than wide (ratio $0.6-1.38: 1$ ); pregravid and gravid proglottides longer than wide (ratio $1.1-2.85: 1$ ). Tegument thick.

Scolex aspinose, 120 long and 150 wide (Fig. 1), with four uniloculate suckers, 50-55 in diameter. Large musculo-glandular apical organ present, 50 long and 50 wide, representing $33 \%$ of scolex width, larger that diameter of suckers $(\mathrm{AOD} / \mathrm{DS}=1.06)$, composed of small gland cells with finely granular cytoplasm and muscle fibres, surrounded by a muscular layer (Fig. 1). Proliferation zone 80 wide.

Internal longitudinal musculature weakly developed, formed by 7-10 bundles of muscle fibres; bundles absent on lateral sides of proglottides (Figs. 4-6). Osmoregulatory canals situated between testes and vitelline follicles, with dorsal canals medial to ventral ones. Ventral canals thin-walled, 10-15 wide, sometimes overlapping vitelline follicles (Figs. 2, 3), with secondary canals directed either inwards (medially) or outwards (laterally - Fig. 3). Dorsal canals thick-walled (surrounded by muscle fibres), about 5 wide, present only in premature proglottides, then atrophied, with muscle fibres forming two bundles on lateral side of mature and gravid proglottides.

Testes medullary (Fig. 4), elongate to oval, in one layer, in two well separated lateral fields (Fig. 2). Testes 45-60 long and 30-50 wide, 46-64 in number $(x=54$, $\mathrm{n}=20, \mathrm{CV}=9 \%$ ) (Figs. 2, 3). Vas deferens strongly coiled, reaching to midline of proglottis, often crossing it in gravid proglottides (Fig. 2). Cirrus-sac thick-walled, 135-175 long and 40-60 wide, representing 18-24\% $(\mathrm{x}=21 \%, \mathrm{n}=15, \mathrm{CV}=8 \%)$ of proglottis width. Cirrus occupies about $75 \%$ of length of cirrus-sac, spinose, i.e. covered with dense spinitriches, c. 2-3 long (Fig. 8). Genital atrium narrow, deep; genital pores irregularly alternating, equatorial to slightly post-equatorial, situated at $48-60 \%(x=54 \%, n=15, C V=6 \%)$ of proglottis length (Figs. 2, 3).

Ovary medullary, bilobed, with dorsal lobes penetrating to cortex (Figs. 5, 6), long narrow isthmus and follicles on dorsal side; ovary 380-525 wide, occupying 57-65\% $(\mathrm{x}=62 \%, \mathrm{n}=15, \mathrm{CV}=4 \%$ ) of proglottis width (Figs. 2, $3,5,6), 110-265$ long, occupying $16-23 \%(x=19, n=30$, $\mathrm{CV}=10 \%$ ) of proglottis length. Relative ovarian size (ratio of ovarian size in relation to that of entire proglottis - see de Chambrier et al. 2012 for methods of measuring) $4.2-5.6 \%$ of proglottis size. Vagina anterior $(50 \%)$ or posterior $(50 \%, \mathrm{n}=104)$ to cirrus-sac, lined with intensely stained cells in its terminal (distal) part, surrounded by circular sphincter near genital atrium (Fig. 8).

Mehlis' gland 45-65 in diameter, representing 6-8\% of proglottis width. Vitelline follicles oval, small, arranged in two lateral bands on each side of proglottis (Figs. 4-6), interrupted on poral side ventrally and dorsally at level of terminal genitalia (cirrus-sac and vagina). Bands of follicles do not reach anterior and posterior margin of proglottides, occupying $80-95 \%$ of proglottis length on poral side and 86-97\% on aporal side (Figs. 2, 3).

Primordium of uterine stem cortical (Fig. 6), already present in immature proglottides, with diverticula in medulla (Fig. 5). Uterus with $14-24(\mathrm{n}=18)$ lateral branches on each side (Fig. 3). Formation of uterus of type 2 according to de Chambrier et al. (2004): uterine stem with small lateral diverticula tipped with conspicuous concentration of numerous intensely stained cells (Figs. 2, 3, 5); lumen appears in last immature and first mature proglottides (Fig. 2). Uterine diverticula present before appearance of first eggs in uterus. Uterine stem and diverticula completely filled with eggs in pregravid proglottides. Thin-walled lateral diverticula grow in gravid proglottides, occupying up to $65 \%$ of proglottis width. Uterus opens in pregravid proglottides by longitudinal, slit-like uterine pore on ventral side (Fig. 3), then enlarges longitudinally to reach almost entire length of pregravid and gravid proglottides.

Eggs with formed oncospheres, i.e. with three pairs of embryonic hooks. Eggs oval to spherical, with thin, hyaline outer envelope, 60-70 in diameter, somewhat collapsed in distilled water (Fig. 7). Inner envelope consists of two-layered embryophore, with thick external layer, 25-27 in diameter, and nucleate envelope of irregular shape. Oncospheres spherical, 15-17 in diameter, with three pairs of embryonic hooks 7-8 long (Fig. 7).

Type host: Enhydris enhydris (Schneider) (Serpentes: Homalopsidae); total length $670 \mathrm{~mm}$, examined on 16 October 2010.

Type locality: Siem Reap (precise locality of capture of the type-host not known, because it was purchased in a local market), Cambodia.

Prevalence and intensity of infection: One of two snakes examined infected with one cestode.

Site of infection: Small intestine.

Etymology: Species is named after Mr. Touch Bunthang from the Inland Fisheries Research and Development Institute in Phnom Penh, Cambodia, who helped to organize sampling trip of the present authors to Cambodia in October 2010.

Type materia 1: Holotype MHNG-PLAT 75447 (one com- 

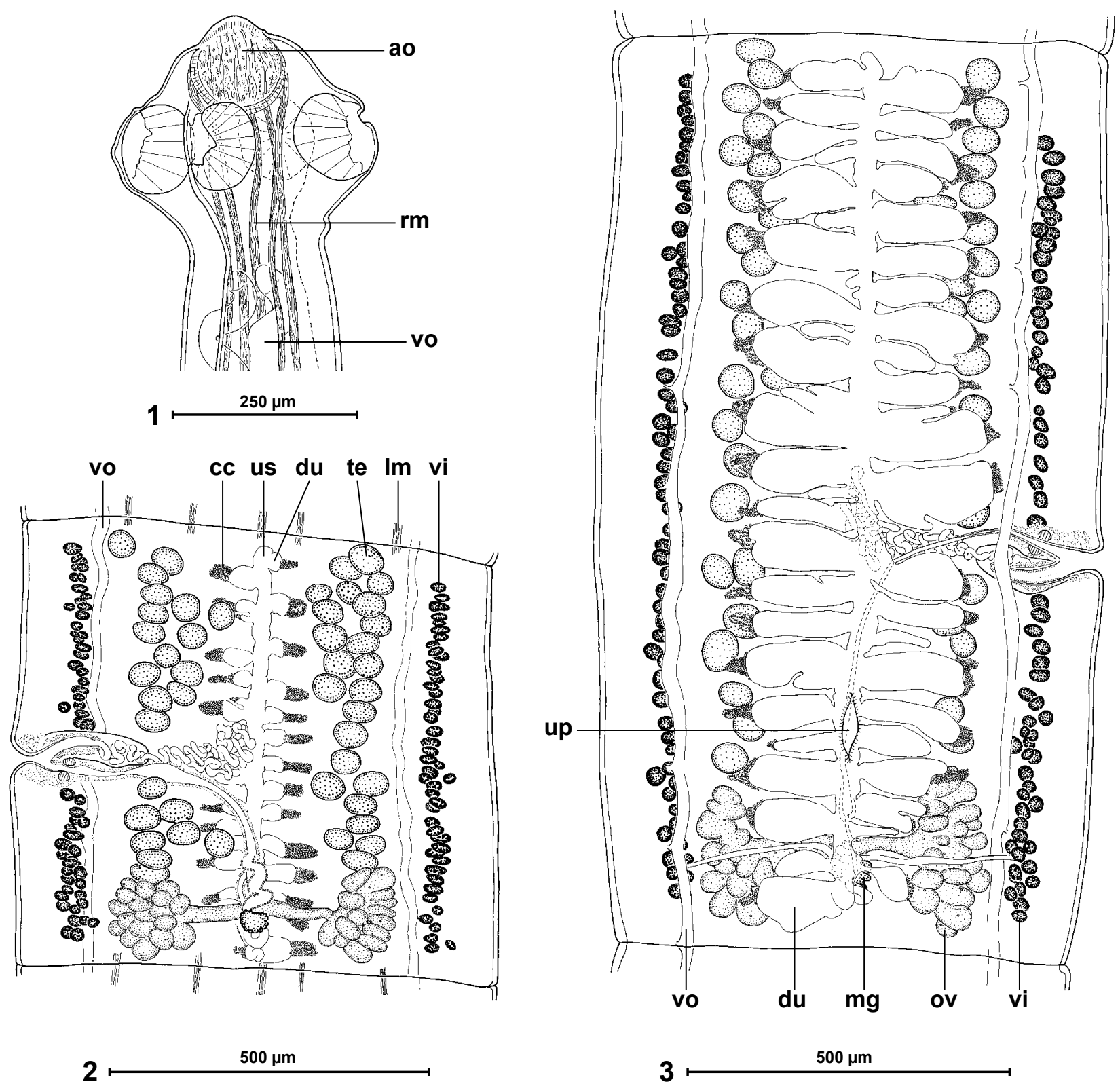

Figs. 1-3. Australotaenia bunthangi sp. n. from Enhydris enhydris from Cambodia; holotype (MNHG-PLAT 75447). Fig. 1. Scolex, sublateral view; note the presence of retractor muscles. Fig. 2. Mature proglottis, dorsal view; longitudinal internal musculature figured only near the anterior and posterior margins of the proglottis; dorsal osmoregulatory canals absent. Fig. 3. Gravid proglottis, ventral view. Abbreviations: ao - apical organ; cc - chromophilic cells; du - diverticula of uterus; $1 \mathrm{~m}$ - internal longitudinal musculature; mg - Mehlis' gland; ov - ovary; rm - retractor muscles; te - testes; up - slit-like uterine pore; us - uterine stem; vi - vitelline follicles; vo - ventral osmoregulatory canals.

plete, whole-mounted specimen on four slides and nine slides with cross sections) and IPCAS C-626 (holotype, one slide with cross sections).

Differential diagnosis: The present species is placed in Australotaenia because of the medullary position of gonads, with the uterine stem in the cortex, scolex with a glandulo-muscular rostellum-like organ, uniloculate suckers, internal longitudinal musculature formed by a few, isolated bundles of muscle fibres, and uterine de- velopment type 2 according to de Chambrier et al. (2004) (de Chambrier and de Chambrier 2010).

Australotaenia contains two species, both described from hylid frogs (Amphibia: Hylidae), namely A. hylae (Johnston, 1912) (syn. Ophiotaenia hylae Johnston, 1912) from southeastern Australia and A. grobeli de Chambrier et de Chambrier, 2010 from Litoria aurea (Lesson) from southwestern Australia (Johnston 1912, de Chambrier 2004, de Chambrier and de Chambrier 2010). 

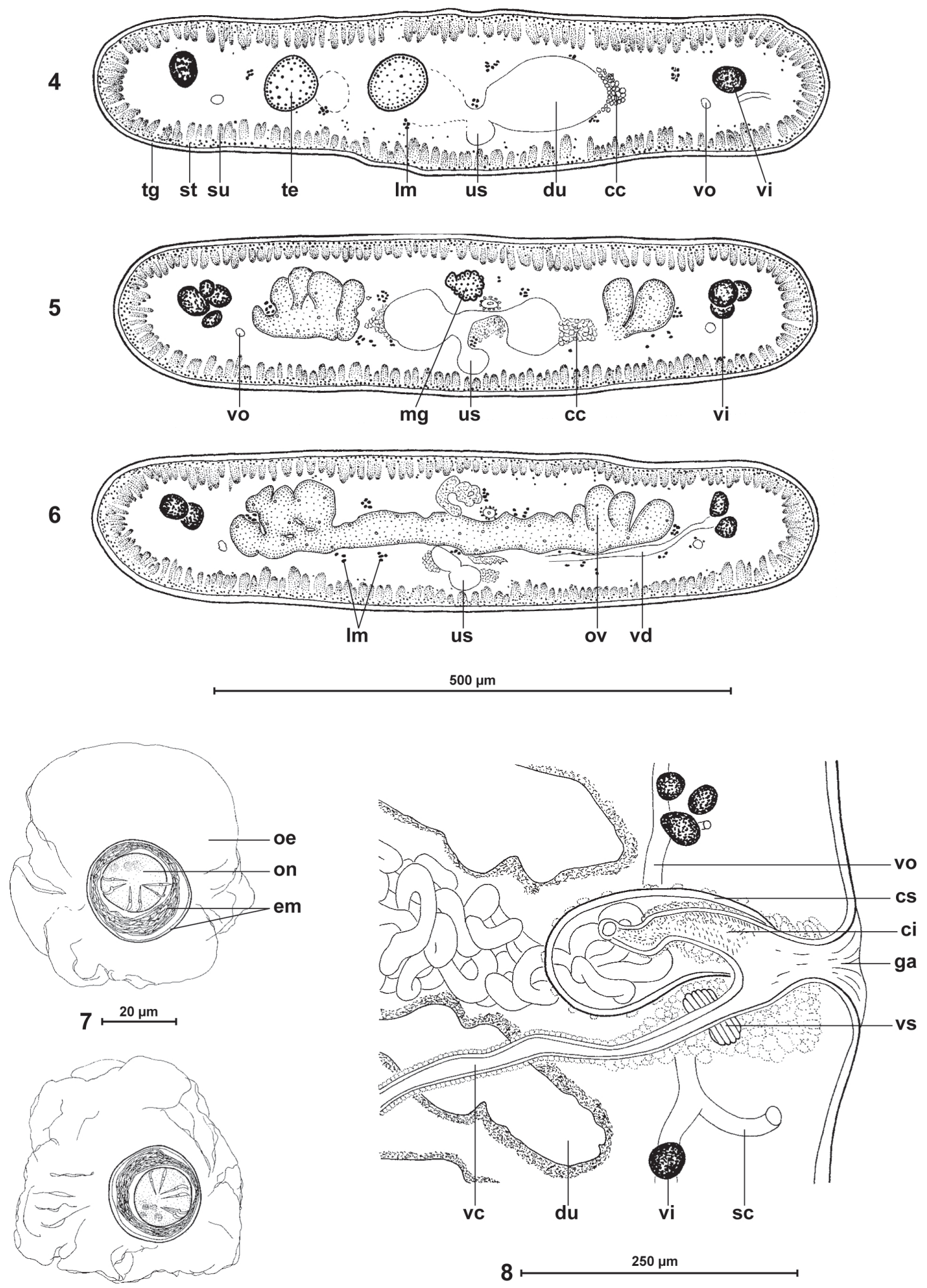

Figs. 4-8. Australotaenia bunthangi sp. n. from Enhydris enhydris from Cambodia; holotype (MHNG-PLAT 75447). Figs. 4, 5. Cross sections at anterior part of a gravid proglottis and at level of the ovary, respectively. Fig. 6. Cross sections at level of the ovary of a mature proglottis. Fig. 7. Eggs drawn in distilled water. Fig. 8. Terminal genitalia, dorsal view. Abbreviations: cc - chromophilic cells; ci - cirrus; cs - cirrus-sac; du - diverticula of uterus; em - embryophore; ga - genital atrium; $1 \mathrm{~m}$ - internal longitudinal musculature; mg - Mehlis gland; oe - outer envelope; on - oncosphere; ov - ovary; sc - secondary osmoregulatory canal; st - subtegumental muscle fibres; su - subtegumental cells; te - testes; tg - tegument; us - uterine stem; vc - vaginal canal; vd - vitelline duct; vi - vitelline follicles; vo - ventral osmoregulatory canal; vs - vaginal sphincter. 
Table 1. Species of Australotaenia (Cestoda: Proteocephalidea), parasites of amphibians and reptiles in Australia and Asia.

\begin{tabular}{llll}
\hline Species & $\begin{array}{l}\text { A. hylae } \\
\text { (Johnston, 1912) }\end{array}$ & $\begin{array}{l}\text { A. grobeli } \\
\text { de Chambrier et } \\
\text { de Chambrier, 2010 }\end{array}$ & Australotaenia bunthangi sp. n. \\
\hline Host & $\begin{array}{l}\text { Litoria aurea } \\
\text { Amphibia: Hylidae }\end{array}$ & $\begin{array}{l}\text { Litoria moorei } \\
\text { Amphibia: Hylidae }\end{array}$ & $\begin{array}{l}\text { Enhydris enhydris } \\
\text { Ophidia: Colubridae }\end{array}$ \\
Country & southeastern Australia & southwestern Australia Cambodia \\
\hline Total length & $121 \mathrm{~mm}$ & $57-98 \mathrm{~mm}$ & $224 \mathrm{~mm}$ \\
Maximum width & 920 & 755 & 830 \\
Width of scolex & $340-390$ & $245-420$ & 150 \\
Diameter of suckers & $130-135$ & $100-140$ & $50-55$ \\
Diameter of apical organ & $65-80$ & $70-110$ & 50 \\
Width of neck & 365 & $200-360$ & 80 \\
Number of testes & $74-106$ & $46-76$ & $46-64$ \\
PGP (\%) & $44-55 \%$ & $46-57 \%$ & $48-60 \%$ \\
RSCS (\%) & $17-19 \%$ & $27-33 \%$ & $18-24 \%$ \\
RSO (\%) & $9.6 \%$ & $5.9 \%$ & $5.6 \%$ \\
RWO (\%) & $68-71 \%$ & $55-63 \%$ & $55-65 \%$ \\
Position of vagina* & anterior/posterior & anterior/posterior & anterior/posterior \\
Vaginal sphincter & present & present & present \\
Number of uterine diverticula** & $10-17$ & $14-21$ & $11-24$ \\
Diameter of embryophore & $13-14$ & $18-23$ & $25-27$ \\
Diameter of oncosphere & $11-12$ & $12-18$ & $15-17$ \\
\hline Type of uterine formation & 2 & 2 & 2 \\
\hline
\end{tabular}

Abbreviations: PGP = position of the genital pore (percentage of the distance of the pore from the anterior margin of the proglottis in relation to the total length of the proglottis); RSCS = relative size of the cirrus-sac (percentage of the length of cirrus-sac in relation to the width of the proglottis); RSO - relative size of the ovary (percentage of the ovarian size in relation to that of the entire proglottis - see p. 40 in de Chambrier et al. 2012 for methods of measuring); RWO = relative width of the ovary (percentage of the width of the ovary in relation to the width of the proglottis); ${ }^{*}$ in relation to the cirrus-sac; ${ }^{* *}$ on one side; \#according to de Chambrier et al. (2004).

Australotaenia bunthangi n. sp. differs from both species from hylid frogs in Australia by (i) the relative size of the apical organ, the diameter of which equals to that of suckers in A. bunthangi (ratio of the width of the apical organ to the diameter of the suckers is 1.06), versus the apical organ being much smaller than the diameter of the suckers, representing less than 2/3 in A. hylae (ratio 0.65 ) and $A$. grobeli (ratio 0.62); (ii) much smaller scolex (width $150 \mu \mathrm{m}$ versus $245-420 \mu \mathrm{m}$ ) and suckers (diameter $50-55 \mu \mathrm{m}$ versus $100-140 \mu \mathrm{m}$; see Table 1 for measurements of individual species); and (iii) larger size of the body (total length $224 \mathrm{~mm}$ versus $57-121 \mathrm{~mm}$; Table 1).

In addition, the new species differs from $A$. hylae in the smaller number of testes (46-64 versus 74-106 in A. hylae), and the ovary width/proglottis width ratio (55$65 \%$ versus $68-71 \%$ in $A$. hylae) (de Chambrier 2004; Table 1). From $A$. grobeli, the new species can be differentiated by relative size of the cirrus-sac, the length of which represents $18-24 \%$ of proglottis width (versus $27-33 \%$ in $A$. grobeli) and by the diameter of the embryophore $(25-27 \mu \mathrm{m}$ versus $18-23 \mu \mathrm{m}$ in $A$. grobeli $)$.

\section{DISCUSSION}

Only one specimen of Australotaenia bunthangi was found in Enhydris enhydris from Cambodia, which would normally prevent us from proposing a new species. However, this cestode is described herein as new for three rea- sons: (1) a complete tapeworm in perfect state was found, enabling us to provide a detailed and exhaustive morphological description, including cross sections, which are crucial for its generic assignment; (2) morphology of the tapeworm is markedly different from that of species of all proteocephalidean genera but one (the only exception represents Australotaenia); (3) the present finding is extraordinary as to the extension of the host and distributional range of a proteocephalidean genus.

Generic assignment of the new tapeworm is based on a number of morphological characters. Two previously described species of the genus, i.e. A. hylae and A. grobeli, share with $A$. bunthangi the following morphological traits:

(i) large granulo-muscular apical organ (see figs. 35, 50 in de Chambrier and de Chambrier 2010; Fig. 1 in the present paper);

(ii) internal longitudinal musculature formed by only $7-10$ bundles of muscular fibres, with no muscles on the lateral sides of proglottides (see figs. 38, 52-54 in de Chambrier and de Chambrier 2010; Figs. 2, 4-6 in the present paper);

(iii) cortical uterine stem, with uterine diverticula developing in the medulla (see figs. 38, 53, 54 in de Chambrier and de Chambrier 2010; Figs. 4-6 in the present paper);

(iv) uterine development of type 2 according to de Chambrier et al. (2004); 
(v) testes in two lateral fields separated medially (see figs. 36, 52 in de Chambrier and de Chambrier 2010; Figs. 2, 3 in the present paper);

(vi) lobes of the ovary with numerous follicles on the lateral and dorsal sides (see figs. 36, 53 in de Chambrier and de Chambrier 2010; Figs. 2, 3, 5, 6 in the present paper);

(vii) two-layered embryophore (see fig. 55 in de Chambrier and de Chambrier 2010; Fig. 7 in the present paper).

Australotaenia hylae and A. grobeli are parasites of hylid frogs and were found only in Australia (de Chambrier and de Chambrier 2010), whereas the new species, A. bunthangi, parasitizes a homalopsid snake in SouthEast Asia, i.e. in another zoogeographical region (Indomalayan or Oriental). The occurrence of congeneric cestodes in such distinct host groups (amphibians and reptiles) and from such distant geographical regions (former Indochina versus southwestern and southeastern Australia) is quite unusual.

The only proteocephalidean genus, the members of which occur both in amphibians and reptiles and are widely distributed throughout several zoogeographical regions, is Ophiotaenia La Rue, 1911. However, this is one of the two most species-rich genera of the order (96 valid species are currently recognized - see de Chambrier et al. 2012, de Chambrier and Gil de Pertierra 2012, Rambeloson et al. 2012) and, in particular, phylogenetic analyses indicate that the genus is polyphyletic, i.e. represents an assemblage of unrelated taxa that form at least three distant clades (de Chambrier et al. 2004). In addition, Ophiotaenia comprises species from amphibians (frogs), for which Rudin (1917) proposed a new genus Batrachotaenia. The validity of the genus was supported by Freze (1965), who provided its more detailed differential diagnosis, but Schmidt (1986) synonymized Batrachotaenia with Ophiotaenia because differential characters used to justify the validity of the former genus were found to be questionable. Rego (1994) followed this synonymy and it is also supported by the present authors (see Chambrier et al. 2012, de Chambrier and Gil de Pertierra 2012, Rambeloson et al. 2012). However, revision of Ophiotaenia is pending and it is almost certain that the genus will be split into several genera differing from each other also by host spectrum and geographical distribution of their species.

Recently, Testudotaenia testudo (Magath, 1924), which is a parasite of turtles, has been found also in bowfin (Amia calva), i.e. in a teleost fish, in Tennessee, USA (de Chambrier et al. 2009), but this finding seems to represent an atypical or accidental infection.

The occurrence of $A$. bunthangi in a snake seems to have been caused by host switching or may be a result of postcyclic parasitism, but the current distribution areas of hosts of species of Australotaenia do not overlap. Hylid frogs of the genus Litoria Tschudi belong to the subfamily Pelodryadinae, which comprises 197 species, all restricted in their distribution to the Australo-Papuan region (Frost 2011). In contrast, 44 currently recognized species of Enhydris Sannini et Latreille occur in Asia and Oceania, with 23 species restricted to South and SouthEast Asia (from Pakistan to southern China) (Uetz 2012). This indicates that host switching of species of Australotaenia may have occurred very long ago. Unfortunately, molecular data on the Australian species of the genus are not available to test this hypothesis using DNA sequences, but preliminary phylogenetic analyses (A. Waeschenbach and D.T.J. Littlewood - pers. comm.) indicate that A. bunthangi belongs among the most basal proteocephalidean cestodes.

The finding of $A$. bunthangi in a snake can be a result of postcyclic parasitism, i.e. the occurrence of adult worms in a predatory host that acquired infection by predation of the definitive host harbouring sexually mature parasites. Postcyclic hosts are common among predators and this phenomenon has also been reported for proteocephalidean cestodes. For example, Proteocephalus percae (Müller, 1780), a specific parasite of percid fish (Scholz and Hanzelová 1998) in the Holarctic, was found in pike (Esox lucius L.), which apparently serves as a postcyclic host (Moravec 1979). Postcyclic parasitism probably exists also in species of Ophiotaenia, the life cycles of which may include one or two intermediate hosts (Freze 1965, Biserkov and Genov 1988, Biserkov and Kostadinova 1997, Scholz and de Chambrier 2003). However, the large size of $A$. bunthangi (total length more than $20 \mathrm{~cm}$ ) does not seem to support the possibility that $E$. enhydris serves only as its postcyclic host, having been infected by the predation of a frog with adult tapeworms.

Australotaenia was placed in the Acanthotaeniinae based on several morphological characteristics (see de Chambrier and de Chambrier 2010). Every genus of this subfamily has its own range of definitive hosts and geographical distribution. Monitors (Varanidae) serve as the exclusive definitive hosts for species of Acanthotaenia von Linstow, 1903 in tropical Asia, i.e. the Indomalayan Region, Kapsulotaenia Freze, 1963 in Indonesia behind the Wallace line, i.e. in the Komodo Island, and in Australia and Papua New Guinea, and Rostellotaenia Freze, 1963 in Africa, whereas elapid snakes (Pseudechis) are hosts of species of Vandiermenia de Chambrier et de Chambrier, 2010 in Australia (Freze 1965, Schmidt 1986, de Chambrier and de Chambrier 2010).

The present finding, as well as a number of new proteocephalidean species recently described from snakes and amphibians (see, e.g., Puga and Formas 2005, de Chambrier et al. 2006, 2010, 2012, Ammann and de Chambrier 2008, Coquille and de Chambrier 2008, Marsella and de Chambrier 2008, de Chambrier and Gil de Pertierra 2012, Gamil 2012, Rambeloson et al. 2012) indicate that the cestode fauna of these vertebrate hosts is 
poorly known. Molecular data, although very scarce and fragmentary, also indicate that the existing classification does not correspond to phylogenetic relationships of individual groups (de Chambrier et al. 2004, Hypša et al. 2005). Thus, further studies are needed to unravel more general patterns in the host specificity and geographical distribution of these parasites of the most ancient lineages of tetrapod vertebrates.

Based on the new information on another member of Australotaenia, the diagnosis of this genus is amended, with newly added characters highlighted in italics:

Australotaenia: Proteocephalidea, Proteocephalidae, Acanthotaeniinae. Medium-sized worms, with acraspedote strobila. Scolex with glandulo-muscular rostellum-like organ. Suckers uniloculate. Internal longitudinal musculature formed by few (usually less than ten) large bundles of muscle fibres; bundles absent on lateral sides of proglottides. Testes medullary, in two fields, in one or two layers. Cirrus spinose, i.e. covered with spiniform microtriches. Vitelline follicles in two lateral bands (cortical or medullary - precise position cannot be determined due to absence of inner longitudinal muscles laterally). Vagina posterior or anterior to cirrus-sac. Mehlis' gland small. Ovary medullary, bilobed, with follicles on dorsal and lateral sides. Uterus with cortical stem, growing in medulla. Uterine development of type 2 according to de Chambrier et al. (2004). Parasites of amphibians in Australia and snakes in Indochina. Type species: Australotaenia hylae (Johnston, 1912).

Currently, the genus Australotaenia comprises three species, but at least one more species that belongs to this genus exists. In the collection of the Murdoch University, Perth, Australia, a proteocephalidean cestode from another species of hylid frogs, Litoria australis (Gray) (Pelodryadinae), collected by R. Hobbs in the Adelaide
River, South Australia in 1978, is deposited. This cestode undoubtedly belongs to Australotaenia because it possesses a large musculo-glandular apical organ, very few bundles of muscle fibers of the internal longitudinal musculature, uterine development of type 2 , folliculate ovary and a cortical uterine stem with diverticula in the medulla. Unfortunately, the quality of the single specimen available is not good enough for describing it as a new species of Australotaenia. Nevertheless, this unpublished report represents another support of the assumption that hylid frogs of the subfamily Pelodryadinae (genus Litoria) in Australia are the most typical hosts of species of Australotaenia. In addition, the occurrence of three different species of Australotaenia in three species of Litoria frogs indicates a strict specificity (oioxenous sensu Euzet and Combes 1980) of proteocephalidean cestodes in amphibians in Australia. Such a strict specificity seems to exist also in proteocephalideans parasitizing reptiles, as demonstrated, e.g., by de Chambrier et al. (2004) and de Chambrier and de Chambrier (2010).

Acknowledgements. The authors are obliged to Dr. Roman Kuchta, Institute of Parasitology, for help with examination of snakes in Cambodia and to Drs. A. Waeschenbach and D.T.J. Littlewood for providing unpublished data. The stay of the authors in Indochina (Cambodia and Vietnam) could not be possible without generous support of Hem Rady in Tonle Sap and Siem Reap, and Touch Bunthang in Phnom Penh, both from the Inland Fisheries Research and Development Institute, Phnom Penh, Cambodia, Tran Thin Binh, Institute of Ecology and Biological Resources, Hanoi, Vietnam, and Dr. Miloslav Jirků, Institute of Parasitology, České Budějovice. The authors also thank Janik Pralong, Florence Marteau and Gilles Roth (all Geneva) for their help with drawings and technical assistance. This study was financially supported by the Institute of Parasitology (institutional support RVO:60077344) and National Science Foundation, USA (PBI award Nos. 0818696 and 0818823).

\section{REFERENCES}

Ammann M., de Chambrier A. 2008: Ophiotaenia gilberti sp. n. (Eucestoda: Proteocephalidea), a parasite of Thamnodynastes pallidus (Serpentes: Colubridae) from Paraguay. Rev. Suisse Zool. 115: 541-551.

Biserkov V., Genov T. 1988: On the life-cycle of Ophiotaenia europaea Odening, 1963 (Cestoda: Ophiotaeniidae). Khelminthologiya 25: 7-14.

Biserkov V., Kostadinova A. 1997: Development of the plerocercoid I of Ophiotaenia europaea in reptiles. Int. J. Parasitol. 27: 1513-1516.

de Chambrier A. 2001: A new tapeworm from the Amazon, Amazotaenia yvettae n. gen., n. sp. (Eucestoda: Proteocephalidea) from the siluriform fishes Brachyplatystoma filamentosum and B. vaillanti (Pimelodidae). Rev. Suisse Zool. 108: 303-316.

De Chambrier A. 2004: Redescription of Ophiotaenia hylae Johnston, 1912 (Eucestoda: Proteocephalidea), parasite of Litoria aurea (Amphibia: Hylidae) from Australia. Rev. Suisse Zool. 111: $371-380$ de Chambrier A., Ammann M., Scholz T. 2010: First species of Ophiotaenia (Cestoda: Proteocephalidea) from Madagascar: O. georgievi sp. n., a parasite of the endemic snake Leioheterodon geayi (Colubridae). Folia Parasitol. 57: 197-205.

de Chambrier A, Binh T.T., Scholz T. 2012: Ophiotaenia bungari n. sp. (Cestoda), a parasite of Bungarus fasciatus (Schneider) (Ophidia: Elapidae) from Vietnam, with comments on relative ovarian size as a new and potentially useful diagnostic character for proteocephalidean tapeworms. Syst. Parasitol. 81: 39-50.

de Chambrier A., Coquille S.C., Brooks D.R. 2006: Ophiotaenia bonneti sp. n. (Eucestoda: Proteocephalidea), a parasite of Rana vaillanti (Anura: Ranidae) in Costa Rica. Folia Parasitol. 53: 125-133.

de Chambrier A., Coquille S.C., Mariaux J., TKach V. 2009: Redescription of Testudotaenia testudo (Magath, 1924) (Eucestoda: Proteocephalidea), a parasite of apalone spinifera (Le Sueur) (Reptilia: Trionychidae) and Amia calva L. (Pisces: 
Amiidae) in North America and erection of the Testudotaeniinae n. subfam. Syst. Parasitol. 73: 49-64.

de Chambrier A., Gil de Pertierra A.A. 2012: Ophiotaenia oumanskyi sp. n. (Eucestoda: Proteocephalidea), a parasite of Lepidobatrachus laevis Budgett, 1899 (Anura: Leptodactylidae) from Paraguay. Rev. Suisse Zool. 119 (4) (in press).

de Chambrier A., Zehnder M.P., Vaucher C., Mariaux J. 2004: The evolution of the Proteocephalidea (Platyhelminthes, Eucestoda) based on an enlarged molecular phylogeny, with comments on their uterine development. Syst. Parasitol. 57: $159-171$

de Chambrier S., De Chambrier A. 2010: Two new genera and two new species of proteocephalidean tapeworms (Eucestoda) from reptiles and amphibians in Australia. Folia Parasitol. 57: 263-279.

Coquille S., De Chambrier A. 2008: Cairaella henrii gen. n., sp. n., a parasite of Norops trachyderma (Polychrotidae), and Ophiotaenia nicoleae sp. n. (Eucestoda: Proteocephalidea), a parasite of Thecadactylus rapicauda (Gekkonidae), in Ecuador. Folia Parasitol. 55: 197-206.

Euzet L., Combes C. 1980: Les problèmes de l'espèce chez les animaux parasites. Mém. Soc. Zool. Fr. 40: 239-285.

Freze V.I. 1965: Proteocephalata in Fish, Amphibians and Reptiles. Essentials of Cestodology. Vol. V. Nauka, Moscow, 538 pp. (In Russian; English translation, Israel Program of Scientific Translation, 1969, Cat. No. 1853, v +597 pp.)

Frost D.R. 2011: Amphibian Species of the World: an Online Reference. Version 5.5 (31 January, 2011). Electronic Database accessible at http://research.amnh.org/vz/herpetology/amphibia/. American Museum of Natural History, New York, USA

Gamil I. 2012: Morphological and molecular studies of Ophiotaenia sp. (Cestoda: Proteocephalidea) a parasite of the sandfish lizard Scincus scincus Linnaeus, 1758 (family: Scincidae). World J. Zool. 7: 65-74.

Hypša V., Š́keřííová A., Scholz T. 2005: Multigene analysis and secondary structure characters in a reconstruction of phylogeny, evolution and host-parasite relationship of the order Proteocephalidea (Eucestoda). Parasitology 130: 359-371.
Johnston H. 1912: Notes of some Entozoa. Proc. Royal Soc. Queensland 24: 63-91.

Marsella C.M.V., De Chambrier A. 2008: Ophiotaenia alessandrae sp. n. (Eucestoda: Proteocephalidea), a parasite of Hyla boans (Anura: Hylidae) from Ecuador. Rev. Suisse Zool. 115: 553-563.

MoraVec F. 1979: Occurrence of the endoparasitic helminths in pike (Esox lucius L.) from the Mácha Lake fishpond system. Acta Soc. Bohemoslov. Zool. 43: 174-193.

Oros M., Scholz T., Hanzelová V., Mackiewicz J.S. 2010: Scolex morphology of monozoic cestodes (Caryophyllidea) from the Palaearctic Region: a useful tool for species identification. Folia Parasitol. 57: 37-46.

Puga S., Formas R. 2005: Ophiotaenia calamensis, a new species of proteocephalid tapeworm from the Andean aquatic frog Telmatobius dankoi (Leptodactylidae). Proc. Biol. Soc. Wash. 118: 245-250.

Rambeloson R., Ranaivoson C., De Chambrier A. 2012: Ophiotaenia lapata sp. n. (Cestoda: Proteocephalidea) from Madagascar: a parasite of the endemic snake Madagascarophis colubrinus (Colubridae). Rev. Suisse Zool. 119 (4) (in press).

Rego A.A. 1994: Order Proteocephalidea Mola, 1928. In: L.F. Khalil, A. Jones and R.A. Bray (Eds.), Keys to the Cestode Parasites of Vertebrates. CAB International, Wallingford, pp. 257-293.

Rudin E. 1917: Die Ichthyotaenien der Reptilien. Rev. Suisse Zool. 25: $14-381$.

SChмidt G.D. 1986: CRC Handbook of Tapeworm Identification. CRC Press, Boca Raton, Florida, 675 pp.

Scholz T., de Chambrier A. 2003: Taxonomy and biology of proteocephalidean cestodes: current state and perspectives. Helminthologia 40: 65-77.

Scholz T., Hanzelová V. 1998: Tapeworms of the Genus Proteocephalus Weinland, 1858 (Cestoda: Proteocephalidae), Parasites of Fishes in Europe. Studie AV ČR, No. 2/98, Academia, Prague, $119 \mathrm{pp}$.

Uetz P. (Ed.) 2012: The Reptile Database. http://www.reptiledatabase.org (accessed in August 2012).

Accepted 7 September 2012 